九州大学学術情報リポジトリ

Kyushu University Institutional Repository

\title{
関節リウマチ患者の関節内末梢性ヘルパーT細胞は自 己反応性である
}

\section{櫻木，高秀}

http://hdl. hand le. net/2324/4496009

出版情報：Kyushu University，2021，博士（医学），課程博士 バージョン:

権利関係: Public access to the fulltext file is restricted for unavoidable reason (3) 
論 文名：Autoreactivity of Peripheral Helper T Cells in the Joints of Rheumatoid Arthritis （関節リウマチ患者の関節内末梢性ヘルパーT 細胞は自己反応性である）

区 分：甲

$$
\text { 論文内容の要旨 }
$$

自己反応性 $\mathrm{CD} 4 \mathrm{~T}$ 細胞は、関節リウマチ（以下 $\mathrm{RA} ）$ の病態に重要な役割を果たして いると考えられている。最近、網羅的解析技術により自己抗体陽性の RA 患者の関節に おいて新規 $\mathrm{CD} 4 \mathrm{~T}$ 細胞サブセットが発見された。この細胞は末梢性ヘルパーT 細胞 (peripheral helper T cell: Tph) と命名され、慢性的な抗原刺激で発現する免疫チェック ポイント分子である PD-1 を強く発現し、抗体産生を誘導するIL21・CXCL13 を産生す る事から、自己抗体産生および RA 病態への関与が注目されている。本研究では RA 関 節内 $\mathrm{Tph}$ 細胞が病原性自己反応性 CD4 T 細胞であるという仮説を検証した。

まずフローサイトメトリー解析にて Tph 細胞の炎症性サイトカイン産生能を確認した ところ、B 細胞補助サイトカインに加えて GM-CSF、TNF- $\alpha$ 、IFN- $\gamma$ などの炎症性サイ トカイン産生能を持つ事が分かった（図 1）。

$$
\text { (inCD4+CD45RA-) }
$$

RA 関節液 stim (PMA+ionomycin)

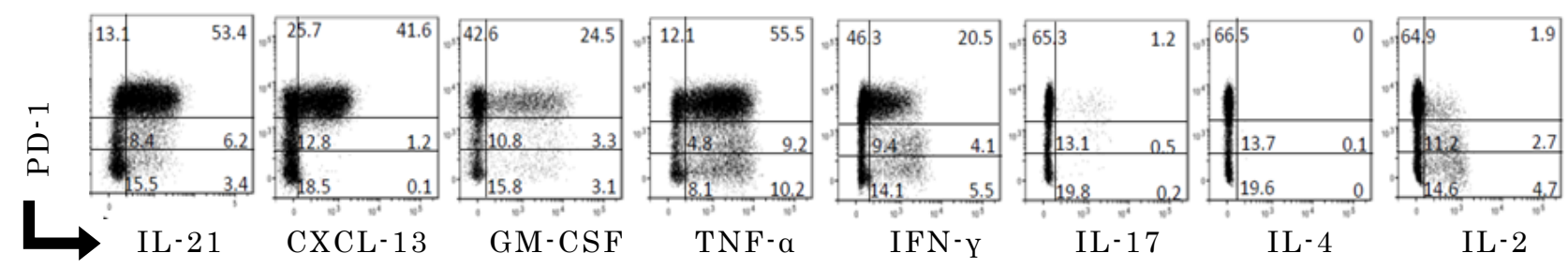

また Tph 細胞は PD-1のみならず、活性化マーカーである HLA-DR・CD69 の発現が有 意に立進しており、自己抗原認識により活性化している可能性が考えられた（図 2）。
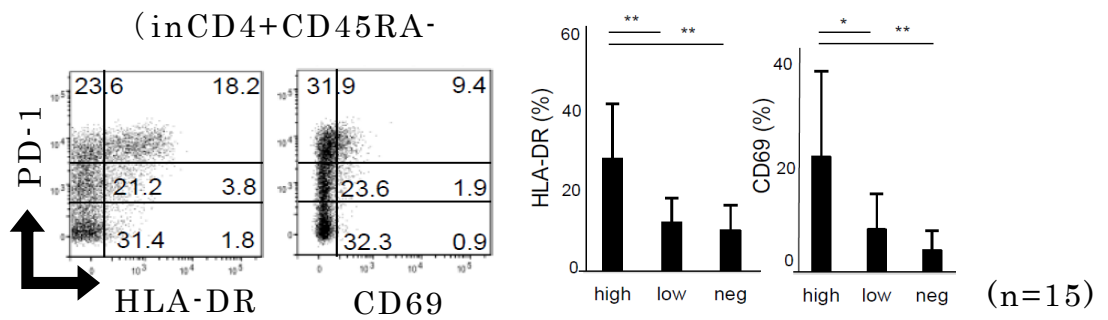

次にフローサイトメトリー解析により PD-1 high $\mathrm{Tph}$ 細胞と Th1 細胞を含む関節内 $\mathrm{PD}-1^{\text {low/neg }} \mathrm{CD} 4 \mathrm{~T}$ 細胞および末梢血メモリー CD4 T 細胞の $\mathrm{T}$ 細胞受容体（以下 TCR） V $\beta$ を比較したところ、PD- $1^{\text {high }} \mathrm{Tph}$ 細胞のTCRレパトアは偏りがみられ、抗原特異性が異 なる事が示唆された（図3）。 

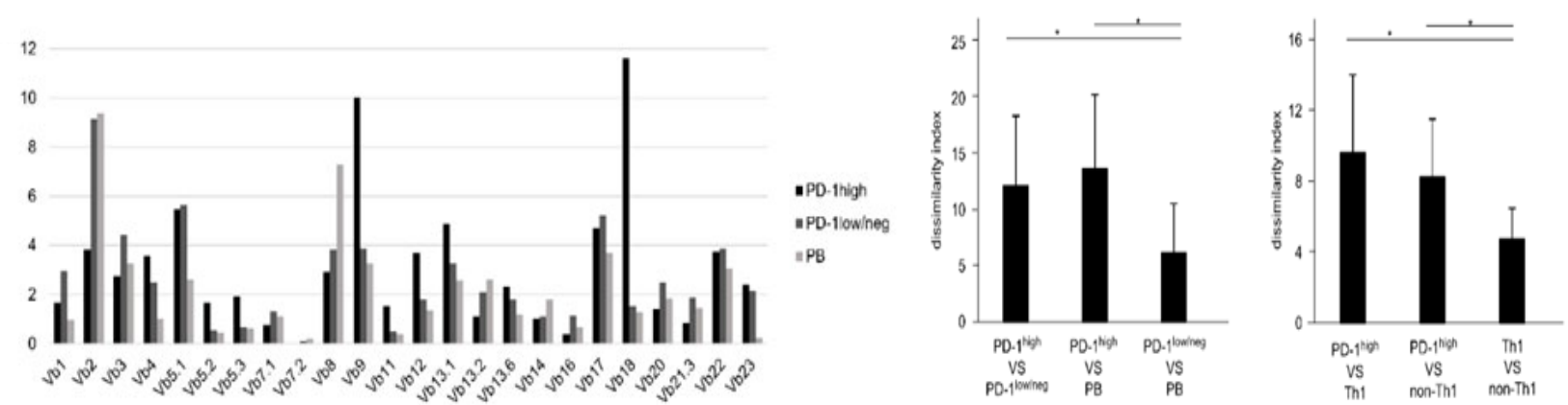

各細胞群をソーティングしTCRディープシークエンス解析を行ったところ、同様に末 梢血メモリーCD4 T細胞と関節内 PD- ${ }^{\text {low/neg }} \mathrm{CD} 4 \mathrm{~T}$ 細胞間には増殖したクローン重複が みられたの対して、関節内 $\mathrm{Tph}$ 細胞との間には重複がみられなかった。類似性を Morisita-Horn indexで評価したところ、関節内 $\mathrm{Tph}$ 細胞と末梢血メモリーCD4 T細胞の類 似性が低いことも実証された（図4）。これらの結果から、関節内 $\mathrm{Tph}$ 細胞コンパート メントでは抗原特異性の異なる $\mathrm{T}$ 細胞クローンが局所的に増殖している事が示された。
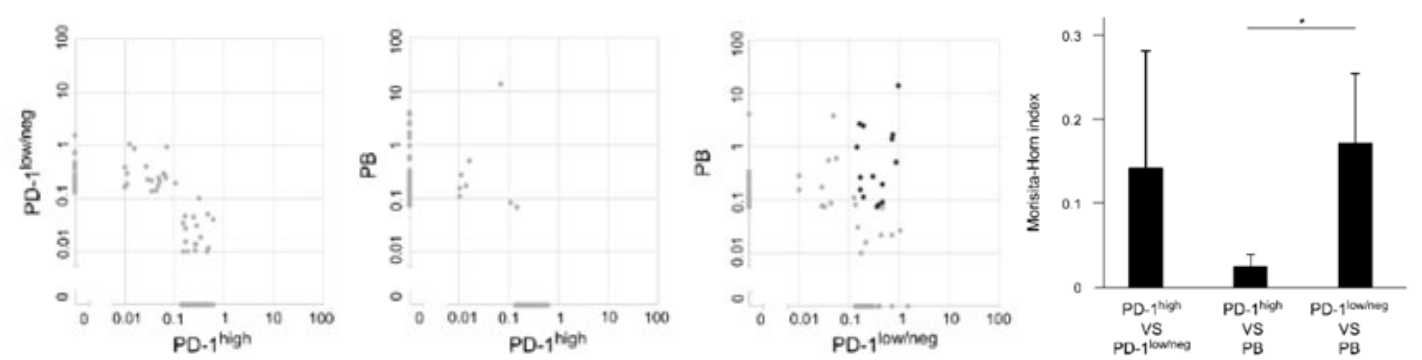

最後に $\mathrm{Tph}$ 細胞の自己反応性を機能的に調べるために自己混合リンパ球増殖反応（以 下AMLR）アッセイを用いた。自己増殖した細胞のほとんどはPD- ${ }^{\text {high }} \mathrm{Tph}$ 細胞でこの 反応は自己MHCクラスIIによる抗原認識を必要とし、PD-1シグナル阻害で増強された

（図5）。これらの結果から、Tph細胞は関節内で局所的に増殖し、PD-1シグナルによ って制御される、RAにおける病原性自己反応性 CD4 T細胞であることが示された。
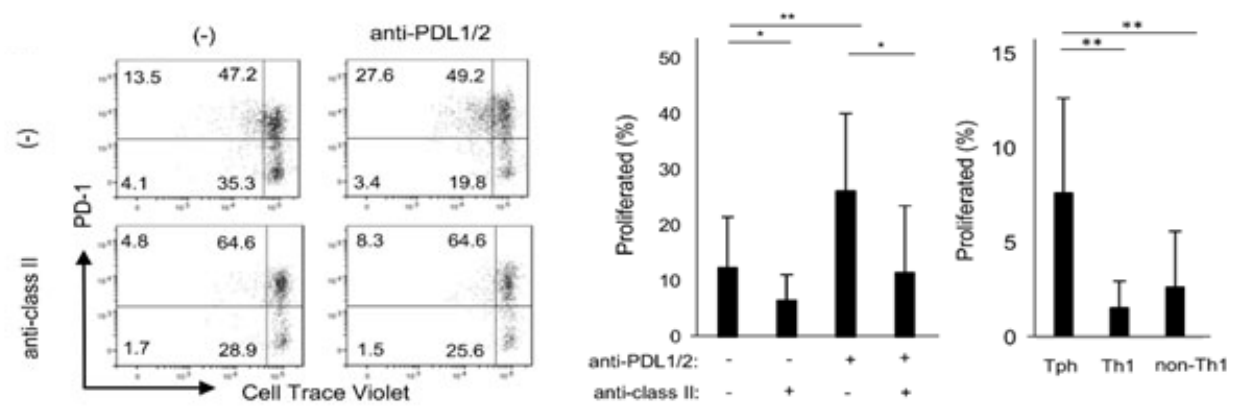